\title{
DAKWAH PERSPEKTIF TABLIGH: KADERISASI MUBALIGH PENULIS
}

\author{
Aep Kusnawan*
}

\begin{abstract}
:
Tabligh, a massive da'wa, can be done in various activities, one of which is through writings in mass media. The increasing number of mass media, such as newspapers, tabloids, magazines, shows information and transparency era. The power of information conveyed by mass media is so dominant that it is necessary for mubaligh's (preachers) to concern with this field. Otherwise, readers will be influenced by the messages in the media which are usually lack of religious values. For that reason, CWC (Creative Writing $\mathrm{Club}$ ) is offered to develop mubaligh's writing skills. It starts with the urgency and the power of writing and continued with how to develop, socialize, and train writing skills as well as other techniques related to $C W C$ to be practiced.
\end{abstract}

Keywords:

Tabligh, mass media, CWC (Creative Writing Club)

\section{Pendahuluan}

Dakwah merupakan proses internalisasi, transmisi, difusi, transformasi dan aktualisasi penghambaan kepada Allah SWT yang berkaitan dengan sesama manusia. Dakwah melibatkan da' $i$, mad'u, uslub, wasilah, dan mad'u dalam mencapai tujuannya seperti dalam QS.al-Maidah: 67, an-Nahl: 44, 125, al-Ahzab: 45,46, al-Jumu'ah:2. Hanya saja penentuan tujuan dakwah ini ditentukan oleh konteksnya.

* Penulis adalah Magister Agama UIN Sunan Gunung Djati Bandung, Dosen Tetap UIN Sunan Gunung Djati Bandung

KOMUNIKA, Vol. I No. 2 Juli-Desember 2007 
Salah satu dimensi dakwah adalah kerisalahan, yang merupakan tuntunan dari QS.al-Maidah ayat 67 dan ali-Imran ayat 104, dengan memerankan tugas Rasul untuk menyeru agar manusia lebih mengetahui, menghayati dan mengamalkan Islam sebagai pandangan hidupnya.

Dakwah risalah dalam prakteknya merupakan proses mengkomunikasikan dan menginternalisasikan nilai-nilai Islam. Ada beberapa media yang dapat digunakan untuk pelaksanaan dakwah risalah misalnya media cetak; surat kabar, tabloid, dan majalah.

Sebagai media massa, surat kabar dan majalah, mensyaratkan adanya informasi yang tidak hanya menghibur, tetapi juga mampu membangun moral bangsa. Hal ini mutlak dilaksanakan, karena media massa memiliki kekuatan dalam mempengaruhi pembaca atau penonton. Jika pembangunan moral bangsa tidak menjadi acuan dari setiap pemilik media maka kahancuran moral anak bangsa akan terjadi. Kekuatan media massa dalam mempengaruhi publik telah dijelaskan oelh berbagai kalanngan, yang menyatakan bahwa media massa sebagai kekuatan keempat setelah legislatif, eksekutif, dan yudikatif

Fenomena seperti itu menjadi tantangan tersendiri bagi dakwah risalah. Karena dakwah risalah mengutamakan pesan moral dan syiar Islam, munculnya kekeringan pesan dari nilai-nilai agama merupakan suatu yang harus diantisipasi dan dihindari. Idealisme seperti itu adalah mulia, namun tidak mudah untuk dilaksanakan Oleh karena itu, diperlukan salah satu cara untuk melakukan kaderisasi terhadap aktivis dakwah sehingga mampu menjadi mubaligh penulis yang mampu melakukan dakwah risalah dengan baik. Permasalahannya adalah sistem apa yang dapat dikembangkan untuk memiliki keterampilan menulis dan tulisan itu menjadi layak untuk dimuat sehingga menulis menjadi sesuau yang menyenangkan dan menguntungkan. Dalam tulisan ini penulis akan memunculkan ide dan pemikiran tentang sistem Creative Writing Club (CWC) dengan harapan bisa melakukan kaderisasi mubaligh penulis.

\section{Menulis Sebagai Kebutuhan}

Jika kekuatan informasi yang disampaikan media massa demikian hebat, itu pertanda bahwa penting bagi para mubaligh untuk bisa masuk ke dalam wilayah itu.Artinya, perlu bagi para mubaligh menyiapkan dirinya 
untuk memiliki keahlian ber-tabligh melalui tulisan di media massa. Paling tidak, ada sebagian di antara kader tabligh yang membidangi aktivitas tabligh-nya melalui tulisan ini. Tanpa sentuhan mubaligh, masyarakat pembaca akan terbentuk oleh pesan-pesan media yang "kering", tanpa nilai-nilai agama.

Kekeringan pesan terjadi karena sebagian besar para pengelola media saat ini lebih berpegang pada kebebasan dan keterbukaan. Mereka dipacu oleh kebutuhan sensasi, iklan, dan kebutuhan bisinisnya. Latar belakang ini memungkinkan media untuk bersikap lebih longgar terhadap isi pesan dan informasi yang dimuatnya. Kelonggaran yang terjadi tidak hanya berdampak positif, namun dapat juga berdampak negatif bagi masyarakat.

Untuk mengantisipasi dampak negatifnya diperlukan adanya pencerahan pesan media massa. Pesan-pesan itu akan muncul dari penulis-penulis yang memang memiliki keterpanggilan akan nilai-nilai kebenaran. Dia adalah para mubaligh, yang tidak hanya mengisi mimbarmimbar ceramah, tetapi juga terampil mengisi lembaran-lembaran koran, tabloid atau majalah, atau yang dikenal dengan Tabligh bi-al-Qalam.

Akan tetapi, bagaimana melahirkan para kader mubaligh penulis tersebut? Untuk menjawab persoalan tersebut, penulis mencoba menyuguhkan secara ringkas mengenai upaya sistematis untuk menumbuhkembangkan keterampilan menulis bagi kader-kader mubaligh pengemban dakwah. Gagasan ini merupakan sistem kaderisasi, yang penulis sebut sebagai Creative Writing Club (CWC). Sistem ini merupakan langkah kaderisasi mubaligh penulis pemula, guna menumbuhkembangkan budaya tulis di antara mereka.

Dengan CWC ini diharapkan dapat muncul kesadaran untuk menulis dikalangan para mubaligh; merakit potensi diri melalui wadah kelompok yang dikelola swa-mandiri, yang out-put-nya dapat mengisi setiap koran, majalah, tabloid, bulletin, bahkan buku dengan kualitas maupun kuantitas tulisan yang kian hari kian meningkat.

Menulis merupakan seni mendayung gagasan, pikiran, ataupun pengalaman. Karya tulis sendiri ibarat sebuah lautan yang seolah-olah tak bertepi. Saat seseorang membaca sebuah karya tulis yang cocok dengan seleranya, ia akan tenggelam ke dalam lautan gagasan, pikiran, dan pengalaman penulisnya. Seperti ketika seseorang berdiri di salah 
satu tepi pantai, lalu ia menatap gelombang yang bergerak menggenapkan pemandangan samudera raksasa, lalu ia mulai berlayar dengan menggunakan perahu dayung. Ia akan menemukan tantangan, kepuasan, atau bahkan mungkin pengalaman perjalanan yang terus mengalir dan hampir sulit dihentikan. ${ }^{1}$

Seperti itulah aktivitas menulis. Merakit kata menjadi kalimat, kalimat menjadi paragraf, serta paragraf terangkai menjadi karya tulis yang bermakna. Tulisan yang baik, ditentukan oleh paragraf yang baik dan paragraf yang baik ditentukan oleh kalimat yang baik. Kalimat yang baik ditentukan oleh kata-kata yang baik. Kata yang baik ditentukan oleh gagasan yang menjiwai kata-kata yang dipilihnya, serta alur berpikir yang dipakainya.

Menulis adalah pekerjaan yang membutuhkan ketekunan, tapi juga menyenangkan. Dengan menulis, pelakunya untuk mengembara ke alam gagasan yang semakin kaya. Menulis berarti juga menambah pengetahuan baru sekaligus mempertajam pengetahuan yang sebelumnya telah tersedia. Tulisan, kata Sayyidina 'Aly 'alaihissalam, merupakan tali pengikat ilmu pengetahuan. ${ }^{2}$

Tidak sedikit orang kaya ilmu pengetahuan, tapi tidak mengikatnya dengan tulisan. Suatu saat ia akan hilang seiring hilangnya usia. Gagasangagasannya akan terlupakan bersama perjalanan waktu. Namanya pun akan berakhir dimakan zaman. Sebaliknya, banyak orang tetap hidup bersama hingga saat ini meskipun jasadnya telah terkubur tanah ratusan tahun silam. Al-Ghazali, misalnya, telah meninggal tahun 1111, tapi ia tetap hadir bersama saat ini, karena tulisan-tulisannya yang mengikat erat namanya untuk tetap hidup dan bahkan terus berkembang. Teoriteori Ibn Khaldun pun tetap dibaca orang, dan dengan teori itu pula orang kemudian mengembangkan teori-teori baru sesuai dengan perkembangan dan perubahan. Demikianlah, sejumlah pemikir dan pemilik ilmu masa lalu, karena tulisan-tulisannya, hingga saat ini masih hadir bersama generasi saat ini.

${ }^{1}$ Asep Saeful Muhtadi, Merakit Tradisi Menulis, dalam pengantar buku Aep Kusnawan, Berdakwah Melalui Tulisan, (Bandung: Mujahid Press), 2004, hal. 10

${ }^{2}$ Ibid. hal. 
Tidak heran jika dalam sebuah hadits yang diterima dari Abi Hurairah R.A, Rasulullah SAW bersabda: "Tiga orang akan selalu diberi pertolongan oleh Allah adalah: Mujahid yang selalu memperjuangkan agama Allah, seorang penulis yang selalu memberi penawar, dan seorang yang menikah untuk menjaga kehormatannya". (HR. Thabrani).

\section{Menulis Membawa Keuntungan}

Siapapun orangnya, jika sampai detik ini mengira bahwa dengan tulisan dapat mendatangkan uang, itu tidak keliru, sebab dengan tulisan yang dibuat kemudian diterbitkan, dengannya berarti penulis telah berjasa, dan karena jasanya itu, secara logis penerbit akan menyampaikan "tanda terima kasih"'-nya kepada penulis. ${ }^{3}$

Jika ada orang menganggap dengan tulisan dapat mempertajam intelektualitas, itu juga tidak salah. Dengan keinginan menulis yang semakin baik, ia akan semakin banyak membaca, baik membaca Qur'an, koran, buku, majalah, atau sumber lainnya. Selain itu ia juga akan semakin sering membaca kondisi, situasi, lingkungan, alam, atau segala macam ciptaan Tuhan dengan berbagai permasalahannya. Dengan demikian, ia akan semakin dituntut peka terhadap berbagai persoalan yang berkembang, dan ia akan semakin merasa haus terhadap segala macam sumber informasi. Bukankah itu merupakan suatu yang mendorong peningkatan intelektualitas? ${ }^{4}$

Mungkin juga seseorang mengira bahwa dengan tulisan dapat meningkatkan popularitasnya, itu juga merupakan hal yang logis. Dengan terbitnya tulisan seseorang, meski ia sendiri berada di ruang kamar dengan pesawat komputer, maka sungguh ia akan dikenal orang. Ia dikenal tidak hanya oleh puluhan orang atau ratusan orang, tidak pula hanya oleh orang di satu kampus, atau satu daerah, tetapi sebanding lebih dengan jumlah oplah yang diterbitkan oleh media yang memuat tulisannya itu, atau sebanding dengan sejumlah orang yang membaca media tersebut, dengan jangkauan wilayah seluas media itu tersebarluaskan. ${ }^{5}$

${ }^{3}$ Ahmad Bahar, Kiat Sukses Meraih Penghasilan dari Surat Kabar, (Yogyakarta: Pena Cendikia ), 1996.

${ }^{4}$ Hernowo (Ed.), Sebuah Buku Setetes Ilmu, (Bandung: Mizan), 1991.

${ }^{5}$ Abu Al-Gifari, Kiat Menjadi Penulis Sukses, (Bandung: Mujahid Press), 2002. 
Akan tetapi, hanya keuntungan yang sifatnya sesaat itukah menulis itu? Sehingga karena sesuatu dan lain hal seseorang masih merasa ragu untuk menekuni dunia tulis, atau barangkali ia tidak cukup terpuaskan karena keuntungan tulisan yang ia tahu, baru terpaku pada batas-batas yang masih pragmatis, sempit dan tidak lebih luas. Umpamanya ia ingin memberikan konstribusi kepada masyarakat atau bahkan lebih dari itu, ingin memiliki "saham" bagi peradaban dunia. Lalu ia bertanya, apakah dengan tulisan keinginannya itu dapat tercapai.

Berkenaan dengan hal itu, penulis mengajak pembaca untuk kembali mengingat sejarah. Betapa sejarah peradaban manusia sebelum mengenal tulisan adalah sejarah yang kelam bagi manusia yang ada pada masa kini. Apa yang dialami oleh umat manusia saat itu, hanya dapat diduga dan diraba atau direkonstruksi dari jejak peninggalan yang tampak dan bekas-bekas yang ditinggalkan, dan itu amat terbatas adanya. Kurun waktu sebelum orang mengenal tulisan itupun disebut sebagai zaman pra sejarah. Saat itu ahli antropologi mencatat, ${ }^{6}$ antara laju peradaban dengan evolusi manusi berjalan berbanding sejajar, peradaban berjalan lambat.

Sementara sejarah peradaban manusia dipandang baru muncul, setelah ditandai oleh keberhasilan manusia menciptakan lambang-lambang yang kemudian disebut huruf, yang pada mulanya dituliskan di dindingdinding gua. Huruf-huruf itu kemudian di rangkai menjadi kata-kata dan disusun menjadi kalimat-kalimat, yang memiliki fungsi untuk mengatakan pikiran-pikiran mereka dari hasil pengalaman yang telah mereka alami. Dengan demikian, jika sebelum orang mengenal tulisan, suatu penglaman atau pemikiran manusia hanya menjadi milik dia atau milik masyarakat yang semasa ketika itu, maka setelahnya mereka dapat menulis dan membaca, pengalaman dan pemikiran tersebut tidak hanya dinikmati oleh generasinya, tetapi oleh generasi sesudahnya, bahkan generasi yang jauh sesudah mereka meninggal. Dengan begitu, pemikiran-pemikiran menjadi tekoleksikan dalam suatu arsip yang bernama tulisan. Sejak itu pula, para sejarahwan mencatat, peradaban manusia mengalami perkembangan yang pesat. hal. $238-140$. 
Gambaran lebih lanjutnya, kita dapat memperhatikan bahwa usia bumi menurut para ahli diperkirakan tercipta sekitar 3.000.000.000 tahun yang lalu. Manusia sendiri telah diciptakan semenjak 2.000.000 tahun yang lalu. Sementara itu manusia baru mengenal tulisan sekitar 200.000 tahun kemudian. ${ }^{7}$ Berarti selama itu pula peradaban mansia berjalan sangat lambat bagai jalannya seekor siput. Percepatan perkembangan peradaban terjadi setelah peradaban manusia terdokumentasikan dan ada yang memelihara serta melestarikan, yaitu dalam bentuk tulisan.

Benih peradaban mulai tumbuh di Mesir Purba dan Babilonia. Kita menyaksikan, adanya upaya mendasar dalam pengembangan ilmu pengetahuan, yaitu melalui observasi dan pengukuran. Orang Mesir mengembangakan teknik perhitungẩn yang sederhana untuk mensurvei tanah. Orang-orang Babilonia mengamati bintang di langit, mengukur panjang tahun dan bulan. Lalu di Yunani orang menambahkan dua unsur lagi yaitu Abstraksi dan Generalisasi. Euclides kemudian mengubah pecahan fakta yang dihimpun oleh orang Mesir dan Babilonia, menjadi sistem logika yang ketat dengan tulisannya Elemeni-elemen Geometri.

Tulisan ini kemudian berpengaruh kepada generasi- sesudahnya, yaitu antara lain spláto dán Aristoteles. Kemudian ratusan tahun berikutnya

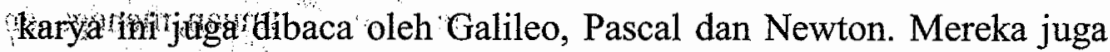
sâmà Newton (1642-1725) berhasil menumbuhkan revolusi ilmu pengetahuan padà masanya. Semua itu tiadilain, di samping atas penemuannya, karena jasa tulisan yang dia baca dari karya-karya paar pendahulunya, seperti Copernicus, galileo, Tycó, Kepler, Euclides serta ilmuwan dan penulis lain sebelumnya. Setelah Newton pun kita kenal seorang yang jenius "Albert Einstein, yang katany a dijuluki "Ayah angkat zaman atom" atau i"Bapak Kosmologi", dengañ pengembangan teori relativitasnya. Semua keberhasilannya dia akui tidak akan terjadi manakala tidak ada para pendahulunya. Jika ia dipandang besar oleh orang lain, maka menurutnya kebesaran itu tiada lain karena ia berdiri di atas bahu raksasa para pendahulunya itu.

${ }^{7}$ J.B.A.F. Mayor Folak, Sosiologi Suatu Buku Pengantar Ringkas (Jakarta: Ichtiar Baru), 1976, hal.20

${ }^{8}$ Rachmat Taufiq Hidayat, Tulisan Buku dan Peradaban, dalam Tim Penyusun, Buku untuk Pribadi Massa Depan, PP, Tasikmalaya, 1992. hal. 16 
Dengan memperhatikan pemaparan di atas, ternyata nampak kehebatan tulisan telah mampu berperan dengan sangat menakjubkan. Betapa tulisan telah mampu menampung, menabung dan mengkoleksi karya-karya serta menyebarkannya. Bahkan tulisan juga telah mampu "mendongengkannya" kepada generasi yang hidup sampai beratus-ratus tahun kemudian.

Pada gilirannya, tulisan bukan hanya mengakumulasi pengetahuan, tetapi juga memungkinkan koreksi, penambahan, penyempurnaan, dan pengembangan pengetahuan yang baru. Tulisan ibarat alat rekam, selain mampu menyimpan memori dari hasil karya rasa dan cipta manusia, juga mampu menerima masukan-masukan baru, sehingga koleksinya kian hari kian bertambah banyak dan semakin baik.

Tidak heran jika para pengamat melihat bahwa perkembangan budaya dan peradaban manusia akhir-akhir ini sangat cepat. Jika dibandingkan dengan evolusi fisik manusia, grafik kebudayaan dan peradabannya itu telah jauh melesat meninggalkan evolusi fisiknya. ${ }^{9}$

Dengan demikian, kini tergambar sudah, jika seseorang mendambakan untuk bisa berhubungan dengan masyarakat, turut dalam mencerdaskan kehidupan umat manusia generasi kini dan kemudian, memberikan informasi berharga, menyampaikan penemuan-penemuan, menegakan idealisme dan keadilan, menyuarakan yang benar sebagai benar dan yang salah sebagai suatu yang salah, atau ia ingin berjuang dan berdakwah untuk peradaban yang bermuatan rahmatan bagi seluruh alam, maka melalui tulisan, hal itu bukan hal mustahil. Sekecil apapun karya tulisnya, tentu akan tetap terkenang dan terarsipkan. ${ }^{10}$

Jika demikian adanya, maka bukan hanya ia yang untung, tetapi akan banyak pihak yang diuntungkan. Tidak pula yang diuntungkan itu hanya satu generasi, tetapi juga bisa berlanjut kepada berbagai generasi sesudahnya, bahkan mungkin jauh sesudah ia tiada. ${ }^{11}$

\footnotetext{
${ }^{9}$ Marwah Daud Ibrahim, Teknologi, Emansipasi dan Transendensia: Wacana Peradaban dengan Wacana Islami, (Bandung: Mizan, Bandung), 1994.

${ }^{10}$ Eertt M. Rogers, Memasyarakatkan Ide-ide Baru, (Surabaya: Usaha Nasional), 1987.

${ }^{11}$ Bandingkan, Abdul Thalib Rahman, Pedoman Penerapan Manajemen Berdasarkan Sasaran, Renjana Swadwsi Utama, Bandung 1990, Syahriman Syamsu Dkk., Dinamika Kelompok dan Kepemimpinan, Unipersitas Atmajaya, Yogyakarta, 1991, Syaikh Faisal Bin Aly Yahya Ahmad, Sistem Kaderisasi Rasulullah SAW, Pustaika Mantiq, Solo, 1994.
} 


\section{CWC Mengkader Mubaligh Penulis}

$\mathrm{CWC}$ atau Creative Writing Club ialah suatu sistem yang diformat untuk merakit sumber daya manusia yang kreatif, dinamis, ikhlas, ingin maju, dan berwawasan ke depan. CWC merupakan gagasan untuk mendorong berkembangnya budaya tulis yang tampaknya kini masih jauh bandingannya dari budaya bicara. Selain itu, CWC dapat memacu kreativitas dan produktivitas intelektual, khususnya di kalangan akademisi, serta pemasaran produk intelektual ke tengah masyarakat. Melalui CWC dapat juga diupayakan pengenalan terhadap dunia luar, yang diharapkan mampu menjalin hubungan kerjasama dengan beberapa pihak terkait, dengan prospek yang saling menguntungkan. Selain itu, dapat juga menciptakan lapangan kerja bagi siapa saja yang menggelutinya.

Dalam sistem kerjanya, CWC dirancang melalui tahapan sosialisasi gagasan, penataan wadah CWC, perekrutan peserta bimbingan, pelaksanaan pelatihan, proses bimbingan, pengadaan tulisan, pengeditan dan konsultasi, revisi tulisan, pengiriman ke media massa yang sesuai, pemantauan pemuatan tulisan, serta penjalinan kerjasama dengan pihak terkait.

\section{Latar Belakang CWC \\ a. Kekuatan}

Jika dicermati lebih seksama, peminat untuk pengembangan potensi di bidang tulis menulis yang bernilai produktif, dewasa ini berkembang relatif semakin besar. Sementara jika diupayakan, keberadaan tenaga pembimbing maupun sarana dan prasarananya pun nampaknya bisa memadai.

b. Kelemahan:

Sampai saat ini, nampaknya belum ada suatu pola pengembangan potensi yang dapat dikembangkan secara swa-mandiri dalam bidang tulis-menulis. Sementara itu, potensi yang ada masih memerlukan bimbingan, pelatihan dan pengembangan.

Akibat keadaan ini, berbagai media cetak, yang kini jumlahnya $b a k$ jamur di musim hujan, masih belum cukup termanfaatkan sebagai lahan praktik menulis atau sebagai lahan pemasaran produk intelektual para insan akademisi di kampus-kampus. Kondisi ini juga ditunjang oleh belum optimalnya pemanfaatan sistem kerjasama pihak kampus dengan pihak media massa atau dengan penerbit buku, yang 
dibuat secara konkret dan saling menguntungkan. Ini berarti pula masih membuka peluang untuk adanya terobosan-terobosan baru.

c. Peluang

Keberadaan suatu perguruan tinggi yang memiliki Tri Dharma pada dasarnya merupakan "gudangnya" konsep-konsep. Dengan demikian, wajar jika berbagai sumber daya yang ada di suatu perguruan tinggi dapat memberikan akses intelektualnya ke masyarakat. Salah satu cara adalah terlibatnya insan akademisnya dalam menulis. Sementara itu, berbagai sumber daya yang ada di dalamnya diberi motivasi, pembinaan, bimbingan, pelatihan, dan pengembangan di bidang menulis yang tidak hanya untuk pengerjaan tugas-tugas, tetapi juga untuk dipublikasikan.

Saat ini, berbagai surat kabar dan majalah telah menjamur, penerbit buku pun ada di mana-mana. Sementara itu, adanya sejumlah dosen muda dan praktisi menulis di kampus-kampus, walau jumlahnya tak banyak, juga merupakan peluang untuk dapat dimintai kesediannya untuk membantu program pembudayaan menulis.

d. Tantangan

Memasuki era informasi dan globalisasi, produk intelektual civitas akademika, suatu perguruan tinggi sangat dinantikan masyarakat. Dengan itu pula masyarakat dapat menilai kualitas suatu perguruan tinggi.

e. Alternatif

Sebagai jalan keluarnya, sudah saatnya diadakan suasana yang mengarah pada terciptanya iklim akademis, yang memberikan motivasi kepada kegairahan menulis. Di samping adanya suatu pola latihan dan bimbingan yang sistemik, yang mengarah kepada penumbuhkembangan skill dosen dan mahasiswa di bidang menulis. Selain itu, diperlukan juga adanya suatu sistem kerjasama dengan pihak luar, yang akan saling menguntungkan. Pola itu sebaiknya dapat dikembangkan dari dan oleh mahasiswa secara kreatif, melalui kelompok-kelompok yang aktif dan kreatif, dengan motivasi serta bantuan dan penghargaan dari pihak struktural kampus.

Gagasan alternatif di atas, selanjutnya dapat diformulasikan dalam suatu bentuk sistem kerja, seperti CWC. CWC merupakan sebuah istilah bagi sebuah sistem yang jika telah diaplikasikan dalam kelompok-kelompok 
nyata, penamaannya dapat disesuaikan dengan kreasi masih-masing kelompok. CWC itu pada dasarnya, sebuah format yang dapat dikembangkan di mana dan oleh siapa saja, terutama kalangan mahasiswa dan insan akademis, dengan indikasi: "Semakin banyak yang mendirikan sistem semacam CWC, maka akan semakin baik bagi tumbuhnya persaingan yang sehat dan pembangunan sistem kerjasama yang semakin produktif dan kualitatif'. ${ }^{12}$

\section{Format CWC}

Visi CWC dibangun di atas visi keislaman, kedakwahan, keilmuan dan pemberdayaan serta visi pencerahan, peningkatan kualitas, keunggulan. Sementara itu, misi yang diemban oleh CWC ialah aktivitas, kreativitas, produktivitas, dan kemandirian, serta kepedulian, kerjasama, latihan, bimbingan, pengembangan dan saling menguntungkan.

Tujuan CWC terciptanya hasil proses yang dapat saling menguntungkan (You win I win) dalam menumbuh-kembangkan budaya tulis, mendorong lahirnya produktivitas bersama yang memiliki daya saing dan daya jual, serta terciptanya lapangan kerja dan kesiapan kerja yang bercirikan nilai akademik.

Untuk mencapai tujuan tersebut, strategi CWC adalah mengupayakan terciptanya suatu pola kerjasama yang dilakukan secara swa-mandiri oleh mahasiswa melalui kelompok-kelompok kreatif, dengan mempergunakan sistem struktur kelompok yang ramping. Sistem itu sendiri mefokuskan perhatiannya secara serius kepada bagaimana meningkatkan kemampuan mereka dalam menumbuhkembangkan budaya tulis, yang terefleksi melalui keterampilan menulis di media massa, baik artikel, berita, resensi buku, fiture, cerpen, dan sebagainya. Sebagai lahannya, dipakai sistem pelatihan, bimbingan dan pelayanan konsultasi.

\footnotetext{
${ }^{12}$ Stuktur ini bisa sifatnya tentatif. Ia bisa dirubah dan disesuaikan sesuai dengan kendisi yang ada. CWC bisa dikelola dengan struktur gemuk atau juga ramping. Bisa dikelola oleh banyak pengurus, bahkan bisa dikelola hanya oleh 3-7 orang. Jika dibandingkan, antara pengurus yang gemuk dan ramping, penulis lebih menyarankan yang ramping. Dengan kepengurusan yang ramping diharapkan masing-masing pengurus bisa kerja sama dan sama-sama kerja, yaitu dengan mengatur sejumlah tugas yang bersinggungan dapat dipegang oleh orang yang sama. Selain itu, dengan kepengurusan yang ramping diharapkan bisa lahir kelompok CWC lain dengan nama yang berbeda, sehingga suasana kompetitif antar wadah CWC akan semakin semarak.
} 


\section{Rancangan Struktur (Tentative)}

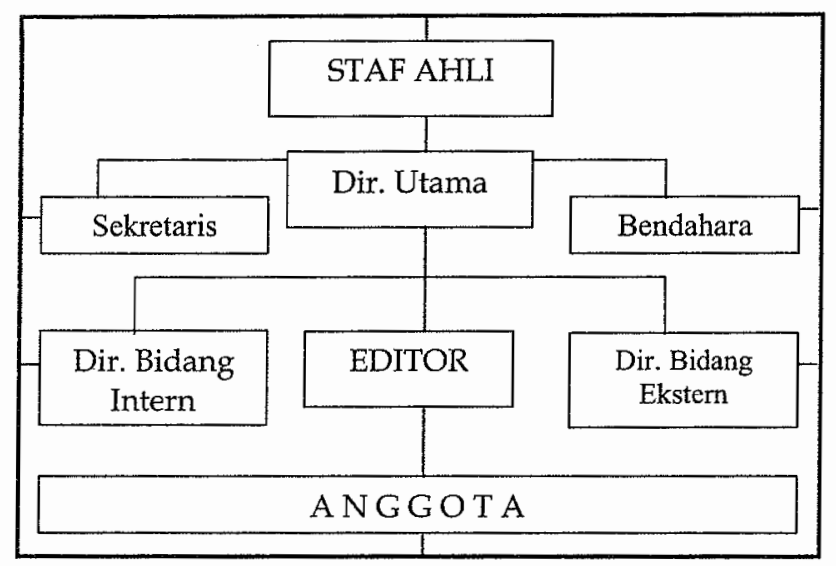

Karena sifatnya tentatif, struktur ini bisa diubah atau disesuaikan dengan kebutuhan, bisa dipersempit, maupun diperluas tergantung kesepakatan anggota kelompok. Gambaran ini hanya sebagai salah satu contoh saja.

\section{Tugas dan Wewenang:}

Staf Ahli memiliki kewenangan untuk memberikan kritik dan saran, serta arahan terhadap kinerja CWC, baik diminta maupun tidak untuk kemajuan CWC. Selain itu, mereka juga memiliki tugas utama, sebagai tenaga editor senior, pelatih senior, pembimbing, dan konsultan senior. ${ }^{13}$

Dirut Utama bertanggungjawab mengkoorinasikan seluruh tim kerja agar harmonis dan dinamis. Ia sendiri juga bekerja secara dinamis, kreatif, dan ikhlas, berusaha memajukan CWC, khususnya dalam litbang dan penjalinan kerjasama.

Sekretaris, ia memiliki tanggungjawab dalam mengurusi bidang kesekretariatan, meliputi bidang: surat menyurat, mengatur administrasi, mendata keanggotaan, mendata setiap naskah masuk, mengatur pengarsipan, mengatur ruang kantor, serta bertanggungjawab dalam membantu tugas Dirut dalam bidang kesekretariatan.

\footnotetext{
${ }^{13}$ Untuk membantu mengarahkan belajar menulis, dapat dibaca dan dipraktikan buku Berdakwah Lewat Tulisan, Karya Aep Kusnawan (penulis), Penerbit Mujahid Press, Bandung, Cet II. Tahun 2004.
} 
Bendahara memiliki tanggungjawab dalam menangani bidang keuangan dan kesejahteraan anggota, dengan rincian: Mengupayakan sebesar-besarnya pendapatan keuangan CWC, mengambil dan mencairkan honorium, mengatur pembagian kesejahteraan pada para pengurus dan anggota $\mathrm{CWC}$ sesuai atauran yang disepakati, dan mengatur pengeluaran keuangan kelompok. Singkatnya, ia membantu dan bertanggungjawab kepada Dirut dalam bidang keuangan dan kesejahteraan.

Direktur Bidang Intern bertanggungjawab mengurusi mekanisme pelatihan, mengurusi mekanisme bimbingan, mengurusi mekanisme konsultasi, mengatur mekanisme editorial, membantu dan bertangggungjawab kepada Direktur Utama dalam menangani kegiatan intern lembaga.

Editor, bertanggung jawab terhadap mutu materi pelatihan, memberikan bimbingan dan konsultasi pada para peserta, memberikan solusi bagi yang berkonsultasi, mengedit karya tulis peserta, memberikan arahan ke media mana sebaiknya suatu tulisan yang dibuat dikirimkan.

Direktur Bidang Ekstern bertugas mengurusi pengiriman naskah kelompok ke media massa, memimpin pemantauan pemuatan tulisan di media massa, mengurusi naskah yang dikembalikan, mengurusi pengarsipan kliping tulisan yang dimuat, mengadakan promosi kegiatan kelompok, mengurusi permintaan ceramah jurnalistik di luar, serta membantu dan bertanggungjawab kepada Dirut Utama dalam urusan ke luar dan menjalin kerjasama yang baik dengan pihak luar terkait.

\section{Mekanisme Kerja}

Mekanisme kerja CWC adalah sebagai berikut.

a. Adanya calon pendiri kelompok. Calon anggota kelompok adalah potensi individu yang dapat dimanfaatkan menjadi potensi bersama dalam suatu wadah kelompok. Calon kelompok bisa berasal dari kawan se-kelas, satu jurusan, mungkin juga lintas jurusan dan lintas fakultas bahkan lintas perguruan tinggi. Asal mereka adalah orang yang siap untuk komitmen, berusaha, berjuang untuk meraih kemajuan bersama dan meraih keuntungan bersama.

b. Pembentukan kelompok. Kelompok dibentuk melalui suatu musyawarah para pendiri kelompok, dengan kesepakatankesepakatan: baik mengenai nama, visi, misi, AD-ART, serta aturan main lainnya. Jumlah pendiri sendiri tidak perlu terlalu banyak, Cukup 
sekitar 3-7 orang. Yang paling penting adalah mereka siap dengan komitmen bersama.

c. Latihan pengurus. Untuk menumbuhkan dan mengembangkan keterampilan menulis secara lebih memadai di antara para pengurus kelompok pendiri, ada baiknya diadakan pelatihan lebih dulu. ${ }^{14}$ Materi yang dibahas, berkisar pada hal-hal yang umumnya dipandang masih dirasa kurang pada para pengurus pendiri. Untuk instrukturnya, pengurus pendiri secara aktif memilih dan memohon kesediaan kepada para praktisi menulis yang ada di wilayah sekitar.

d. Pengurus aktif menulis. Setelah para pengurus pendiri mengikuti pelatihan, maka pengurus tidak boleh pasif, melainkan harus terus aktif menulis, sampai ada di antara tulisan pengurus pendiri yang dimuat di media massa. Bahkan kalaupun sudah dimuat, maka keaktif-an menulis harus lebih terpacu. Jika tulisan masing-masing pengurus pendiri telah dimuat, maka rayakanlah dengan rasa syukur dan terus menulis.

e. Pelatihan peserta. Untuk menebarkan keterampilan menulis yang telah dimiliki oleh masing-masing pengurus pendiri kepada kawan-kawan yang lain, pengurus pendiri dapat berinisiatif mengadakan pelatihan menulis bagi para peserta lain, yang dikoordinir oleh Dir. Bid. Intern. ${ }^{15}$

f. Pelatihan. Pelatihan dapat diadakan secara kondisional, dengan penyelenggaraannya disesuaikan dengan kebutuhan peserta. Bisa pelatihan tingkat dasar, tingkat menengah atau komprehenshif.

g. Media latihan. Sebagai ajang praktek dari hasil pelatihan, pengurus kelompok dapat menyediakan ýmading atau buletin jurnalistik yang

\footnotetext{
${ }^{14}$ Biasanya, jika suatu kelompok telah banyak melahirkan karya yang dimuat di media massa. Itu akan menjadi alat publikasi "gratis" yang efektif untuk mengundang calon peserta yang ingin dilatih menulis. Mereka bahkan siap untuk membayar biaya pelatihan. Mereka umumnya tahu, pelatihan akan menjadi sebuah investasi. Sebab jika mereka berhasil, sejumlah uang yang dibayarkan akan segera kembali dari honor menulis, bahkan mereka akan mendapatkan keuntungan lain yang berlipat.

${ }^{15}$ David Cambell, Mengembangkan Kreativitas, Kanisius, Yogyakarta,Cet. III, 1990. Joyce Wycoff, Menjadi Super Kreatif Melalui Metode Pemetaan Pemikiran, Kaifa, Bandung, 2002. Norma Youngberg, Creative Techniques, Pasific Press, Montain View, California, 1968. Katyn Lindskoog, Creative Writing for The People Who Can't Wrrite, Academie Books, Grand Rapids, Michigan, 1989. Wilson Nadeak, Bagaimana Menjadi Penulis yang Sukses, Pustaka Wina, Bandung 1994. Wilson Nadeak, Bagaimana Menjadi Penulis Artikel Kristiani yang Sukses, (Bandung: Yayasan Kalam Hidup), 1989.
} 
dikelola mulai dari cara sederhana sampai dalam bentuk yang terbaik, sesuai kemampuan kelompok.

h. Penulisan naskah. Baik para pengurus kelompok, mapun para peserta pelatihan yang telah menjadi anggota kelompok, secara aktif menulis.

i. Pencatatan naskah masuk. Agar kelompok memiliki data yang akurat, maka setiap naskah yang telah dibuat sebaiknya, dicatat oleh sekretari kelompok. Untuk selanjutnya dilakukan editing.

j. Editing. Editing dapat dilakukan secara mandiri, yaitu oleh pengurus pendiri yang dianggap telah memiliki kemampuan di bidang tersebut. Atau jika belum ada diantara pengurus pendiri yang mampu, bisa juga meminta bantuan kepada para teoritisi dan praktisi menulis yang dipercaya kelompok sebagai staf ahli kelompok.

k. Bimbingan konsultasi. Untuk lebih menambah pemahaman dan keterampilan yang dimiliki dalam menulis, disamping karya tulis mendapat jasa editing, kelompok juga dapat mengalokasikan jadwal tertentu untuk dibuka waktu Bimbingan dan Kosnsultasi. Untuk konsultannya bisa dipinta kesediannya kepada Staf Ahli kelompok.

1. Revisi. Setelah mendapatkan editorial dari editor, jika naskah ada yang perlu direvisi, naskah dikembalikan kepada penulisnya untuk diperbaiki.

m. Pengiriman ke media yang sesuai. Jika naskah yang diperbaiki sudah dipandang layak untuk dikirimkan, maka naskah dapat dikirimkan ke media yang dipandang sesuai dengan karakter tulisan yang dibuat.

n. Pemantauan pemuatan. Setelah dikirim, maka segenap anggota dan pengurus kelompok mengadakan pemantauan tulisan. Pemantauan juga bisa bekerjasama dengan tukang koran atau yang lainnya. Dengan catatan sambil terus berkarya dengan tulisan yang lain.

o. Jika tidak dimuat (dikembalikan). Akan ada kemungkinan tulisan yng sikirim dimuat, ada juga kemungkinan tidak dimuat. Dan jika tidak dimuat ada kemungkinan naskah tidak dikembalikan dan dikembalikan. Jika naskah dikembalikan, maka bisa dilakukan revisi ulang.

p. Pengiriman ke media lain. Jika ternyata naskah yang dikirim tidak dimuat di suatu media, maka naskah dapat dikirimkan ke media lain yang levelnya lebih rendah, setelah diadakan revisi ulang. 
q. Arsip. Naskah yang telah dibuat, senantiasa dibuat copynya, untuk dimasukan kepada file arsip, sebelum yang aslinya di kirim ke media. Begitu juga kliping yang dimuat juga dicopy lalu diarsipkan

r. Pemuatan. Jika hasil pemantauan ternyata tulisan kelompok dimuat, maka rayakanlah keberhasilan tersebut dengan penuh syukur.

s. Pencairan honor. Sebagai tanda terimakasih penerbit akan memberikan honor pada penulis. Dalam teknisnya ada penerbit yang perlu diambil honornya ada juga yang mengirimkannya via wesel atau transfer rekening.

t. Pembagian honor. Setelah honor diterima, sebaiknya honor tersebut tidak langsung dihabiskan dulu, ingat kebutuhan bagi kemajuan kelompok, sisihkan sekedarnya seukuran yang telah disepakati. Kemudian ingat juga infaqnya bagi yang berhak menerimanya, sisanya baru bagi penulis unţuk kepentingan pribadi dan keluarga yang bermanfaat.

u. Penjalinan kerjasama. Kegiatan kelompok seperti CWC ini amat memungkinkan melakukan hubungan kerjasama dengan pihak luar untuk pengembangan kegiatannya.

v. Dengan penerbit buku. Dalam bidang penulisan resensi buku, kelompok CWC dapat mengadakan kerjasama dengan pihak penerbit buku. Betapa tidak, penerbit buku akan sangat beruntung jika buku yang diuterbitkannya ada yang diresensi di media massa. Karena dengan demikian berarti berlangsung pengiklanan buku secara gratis. Sementara pihak CWC juga beruntung selain akan mendapatkan imbalan dari penerbit buku tersèbut berupa uang, ada juga penerbit yang secara langsung memberikan buku terbarunya untuk kembali diresensi. Bahkan jika kelompok CWC sudah sering meresensi buku dari suatu penrebit, biasanya penerbit buku akan menjadikannya sebagai tim peresensi tetap yang juga mendapat imbalan tetap dari penerbit buku tersebut.

w. Lembaga. CWC juga dapat mengembangkan kerjasamanya dengan lembaga-lembaga lain, seperti: lembaga dakwah, aktivis masjid, lembaga kampus, sekolah-sekolah, ormas-ormas, orpor-orpol, LSM dan sebagainya, dalam bentuk jasa pelatihan dan konsultasi pengembangan menulis. 
x. Dengan individu. Kerjasama CWC juga dapat dilakukan kepada individu yang membutuhkan jasa bimbingan, konsultasi dan etiding, maupun privat penulisan.

y. Penyusunan Bunga Rampai. Jika arsip tulisan telah dianggap cukup, maka kelompok CWC juga dapat secara kreatif mengkalisifikasikannya ke dalam tema-tema tertentu yang saling berkaitan dalam sebuah bunga rampai.

z. Penerbitan buku. Jika telah dianggap cukup pengklasifikasian di atas, maka bunga rampai dapat diterbitkan menjadi sebuah buku karya kelompok CWC tersebut.

\section{Gambaran Masyarakat Pemakai Jasa CWC}

Pada perkembangan selanjutnya jasa CWC diperkirakan akan dibutuhkan secara intern kampus, yaitu mahasiswa dan dosen pada setiap jurusan pada setiap fakultas pada perguruan tinggi yang bersangkutan.

Secara ekstern, jasa CWC ini akan dibutuhkan oleh mahasiswa perguruan tinggi lain, para pelajar, para aktivis masjid, dakwah, ormas, perusahaan, LSM, juga masyarakat umum.

\section{Sosialisasi Gagasan}

Gagasan CWC ini bisa tumbuh dan berkembang melalui tiga jalur: Pertama, Tumbuh sendiri dari kalangan mahasiswa atau dosen. Melalui daya kreatif yang dimilikinya, mahasiswa atau dosen menghimpun diri dalam suatu kelompok kreatif. Dengan cara ini, mereka hanya membutuhkan penjelasan tentang gagasan CWC ini sebagai bandingan bagi gagasan yang mungkin telah terancang secara kreatif di antara mereka, atau mungkin yang sudah dijalankan. Kedua, ditunjang oleh political will kebijakan struktural kampus. Mengingat pola CWC ini dapat membawa peningkatan nama baik kampus tempat CWC, semestinya pihak yang memiliki kebijakan kampus (apapun jenis strukturalnya) dan peduli terhadap pemberdayaan dan pengembangan aktivitas mahasiswa dan dosen ke arah kreativitas dan produktivitas, serta visi academic oriented, memberikan inisiatif dan dukungannya.

Melalui cara ini, selain sosialisasi gagasan seperti pada poin (1), ditunjang juga dengan pemberian dorongan/motivasi yang merangsang 
tumbuh dan berkembangnya kelompok kreatif di kalangan mahasiswa. Misalnya: (a). Pihak struktural kampus memberikan anjuran dan tugas kepada para mahasiswa untuk secara kreatif membentuk kelompok kreatif semacam CWC ini. Dengan demikian, di setiap kelas bisa terdapat 5-10 kelompok kreatif. (b) Bagi mereka yang aktif dan kreativitasnya berkembang dengan banyaknya karya-karya produktif mereka, pihak struktural memberikan penghargaan, baik sebagai salah satu kredit poin, maupun sebagai salah satu kriteria berhaknya memperoleh beasiswa. (c) Sebagai timbal balik, pihak kampus diberi bukti aktivitas dan kretivitas mahasiswa dalam bentuk photo copy kliping tulisan yang telah dimuat di media massa, yang kemudian dicatat dan diarsipkan oleh salah seorang yang diberi tugas untuk itu. Dengan cara itu, mahasiswa akan lebih termotivasi untuk kreatif dan produktif, penuh karya cipta yang inovatif dan semakin berkembangnya iklim akademik yang kondusif.

Demikian juga untuk para dosennya. Bagi mereka diberi dorongan/ motivasi yang merangsang kepada tumbuh dan berkembangnya kelompok kreatif di kalangan para dosen. Misalnya: (a). Pihak struktural kampus memberikan anjuran dan tugas kepada para dosen untuk secara kreatif membentuk kelompok kreatif semacam CWC ini. Dengan demikian, di setiap fakultas bisa terdapat 5-10 kelompok kreatif. (b) Bagi mereka yang aktif dan kreativitasnya berkembang dengan banyaknya karya-karya produktif mereka, baik berupa artikel maupun buku, pihak struktural memberikan penghargaan yang layak dan menggairahkan, (c) Sebagai timbal balik, bukti dari aktivitas dan kretivitas dosen di kelompok kreatif, pihak kampus menerima photo copy kliping tulisan, atau buku dari dosen yang bersangkutan yang telah diterbitkan, yang kemudian dicatat dan diarsipkan oleh salah seorang yang diberi tugas untuk itu.

Selain itu, semakin sering diadakan pameran produk karya tulis dosen dan mahasiswa, serta berbagai kesempatan bedah karya tulis dosen dan mahasiswa, juga akan menggairahakan terjadinya budaya tulis. Sehingga dengan cara itu, mahasiswa dan dosen akan lebih termotivasi untuk kreatif dan produktuf, penuh karya cipta yang inovatif dan semakin berkembangnya iklim akademik yang baik. 


\section{Kelayakan Gagasan Untuk Diaplikasikan}

Minimal ada tiga pertanyaan yang dapat dijawab untuk menguji apakah suatu gagasan dapat dipandang strategis untuk diaplikasikan:

a. Apakah punya daya hidup (viable)?

Jawaban dari pertanyaan itu ialah bahwa keahlian menulis dengan segala bentuknya, sangat dituntut untuk dimiliki, tidak hanya oleh calon jurnalis, tetapi juga oleh ilmuwan dan calon ilmuwan yang berkualitas. Dengan karya tulisnya itu, antara lain, seorang ilmuwan akan dipandang keilmuwanannya. Sebaliknya, tanpa karya tulis, orang akan sulit melihat kepakaran dan kecendekiaannya.

Gambaran itu pula yang kita peroleh dari para ilmuwan dan cendekiawan serta ulama tempo dulu, mereka dapat dikenal hingga kini, karena karya-karya tulisnya yang menyebar dan monumental. Sehingga jauh hari setelah ketiadaan mereka pun kita sekarang masih dapat menikmati dan tercerahkan atas karya tulis mereka.

Kemudian, dengan menjamurnya jumlah media massa yang lahir dewasa ini, menjadikan peluang untuk menjadikan menulis sebagai pekerjan yang tidak pernah tertutup bagi siapa pun yang dapat memanfaatkannya. Bahkan ada kecenderungan, sebagaian media massa kekurangan bahan tulisan yang bermutu untuk dipublikasikan, sementara media massa yang telah lebih bonafid, cenderung memuat karya tulis orang yang itu-itu juga.

Struktur maupun mekanisme CWC rasanya tidak sulit, bersifat fleksibel (bisa diperkecil maupun diperbesar). Bisa dikelola oleh lebih lima orang, kurang dari lima orang, bahkan tiga dan dua orang pun jadi.

Jika CWC ditangani oleh pihak struktural kampus, akan lebih baik jika kelompok yang tumbuh dapat hidup dengan meregenerasi, dengan sistem pengkaderan intensif. Dengan begitu, mahasiswa pendiri suatu kelompok kreatif dapat menggaet kawan-kawan calon penulis pemula lainnya, terutama mahasiwa baru atau tingkat satu. Dengan demikian, para penulis di kampus terjaga kuantitas maupun kualitasnya. Mereka akan senantiasa dalam jumlah yang banyak, dan dalam keadaan seperti itu pula menulis telah jadi budaya dan menjadi bagian dari aktivitas civitas akademika. 
Sementara para aktivis yang menjelang akan menjadi alumni, mereka telah memiliki kesiapan untuk menapaki dunia kerja di lapangan nyata. Bersama kesiapan yang telah ditata dan dijalin sekian lama, sewaktu aktif sebagai mahasiswa, dalam kelompok kreatif, mereka jadi alumni yang penuh rasa percaya diri dan kesiapan memasuki dunia kerja.

b. Apakah yang bisa dikerjakan (workable)?

Untuk Lembaga Perguruan Tinggi, dengan adanya CWC berarti, adanya upaya peningkatan kualitas dosen dan mahasiswa yang menunjang akademis, yang dilakukan dosen dan mahasiswa secara swa-mandiri. Melalui aktivitas yang dilakukan oleh dosen dan mahasiswa menulis di media massa, secara otomatis juga lembaga perguruan tinggi akan semakin sering terpublikasikan lewat karya bermutu para dosen dan mahasiswanya. Semakin banyak produk intelektual terpublikasikan, maka suatu perguruan tinggi bersangkutan akan semakin banyak dikenal dan dirasakan sumbangsihnya di tengah masyarakat. Dengan semakin banyaknya karya intelektual mahasiswa dipasarkan ke tengah masyarakat, maka akan semakin "berkibar" pula nama sebuah perguruan tinggi, dengan keharuman nama, sebagai "pencetak" insan akademis yang berkualitas. Jika produktivitas intelektual sebuah institusi perguruan tinggi telah dipandang baik oleh masyarakat, maka secara otomatis pandangan dan minat masyarakat untuk memasukan "kadernya" ke perguruan tinggi tersebut akan semakin tinggi.

Sementara itu juga, dengan data arsip dan kliping tulisan dosen mahasiswa yang diterima pihak struktural kampus, pihak kampus akan memiliki data-data berharga dari salah satu aktivitas penting karya ilmiah dosen dan mahasiswa, yang membantu dalam menunjang akreditasi lembaga kampus, dan tidak menutup kemungkinan pada suatu saat bisa dipamerkan, bisa disimpan di perpustakaan, atau mungkin bisa dibukukan dalam suatu buku jenis bunga rampai yang kelak dapat dipublikasikan kembali ke tengah masyarakat dalam berbetuk buku, karya inovatif mahasiswa suatu jurusan, atau suatu fakultas, atau mungkin suatu perguruan tinggi.

Semakin banyak dosen dan mahasiswa yang telah biasa kreatif dan produktif serta menjalin kerjasama dengan dunia luar, 
akan semakin mudah bagi para alumni perguruan tinggi untuk memperoleh lapangan kerja. Semakin banyak para alumni yang berkualitas dengan pekerjaannya, maka akan bertimbal balik pada meningkatnya nilai akreditasi suatu perguruan tinggi.

Untuk dosen dan mahasiswa, keuntungan aktif di kelompok kreatif seperti CWC, terutama bagi penulis pemula, akan merupakan peluang sekaligus kesempatan untuk berlatih melalui sistem kerjasama. Dengan semakin banyak berlatih menulis berarti akan semakin banyak membaca. Begitu juga, ia akan semakin merasa perlu memperhatikan apa pun yang disampaikan oleh dosen, karena bisa jadi dari sana akan berambah aspirasi untuk dijadikan bahan tulisan. Tidak hanya itu, ia akan semakin memiliki kepekaan terhadap keadaan dan persoalan sekitar serta berbagai ciptaan Allah lainnya, karena ia merupakan sumber inspirasi bagi tulisan yang akan dibuat.

Melalui tulisan yang pernah dimuat, kemudian diklipingkan, maka kliping tersebut dapat dimanfaatkan sebagai bagian dari tugas mandiri, terhadap mata kuliah yang sesuai dengan tema yang ditulis. Dengan demikian, mahasiswa penulis akan memiliki nilai tambah karena kreativitasnya dalam membuat karya yang sebelumnya tidak ditugaskan secara terstruktur. Tidak mustahil karena itu, ia akan memperoleh nilai akademik yang istimewa. ${ }^{16}$

Selain itu, menulis di media massa dengan sendirinya juga penulis dapat diuntungkan dengan beberapa keuntungan, antara lain: (a) terpeliharanya idealisme; (b) berdakwah dan mendidik masyarakat; (c) popularitas; (d) keuangan; (e) relasi untuk kemungkinan kerja di masa depan. ${ }^{17}$

Bagaimanapun, semakin banyak menyusun konsep dalam tulisan, maka akan semakin terbiasa dan senantiasa memelihara gagasan sampai pada idealisme. Jika tulisan yang dibuat ternyata dimuat di media massa, maka tulisan itu akan dibaca banyak orang,

${ }^{16}$ Baca, Dja'far H. Assegaf, Jurnalistik Masa Kini, Ghalia Indonesia, Jakarta, 1992, Eertt M. Rogers, Memasyarakatkan Ide-ide Baru, Usaha Nasional, Surabaya, 1987, FX Koesworo, Di Balik Tugas Kuli Tinta, (Surakarta: Universitas Sebelas Maret), 1994.

${ }^{17}$ Syahriman Syamsu Dkk., Dinamika Kelompok dan Kepemimpinan, (Yogyakarta: Universitas Atmajaya), 1991.

KOMUNIKA, Vol. I No. 2 Juli-Desember 2007 
dimana orang belajar dari tulisan itu, yang berarti penulisnya telah mendidik masyarakat. Semakin sering tulisan dimuat maka otomatis penulis akan semakin dikenal, dan menjadi populerlah ia di tengah masyarakat pembaca. Selain itu juga penulis akan semakin banyak mendapatkan penghasilan berupa honorium dari penerbit, serta semakin banyak berhubungan baik dengan pihak terkait.

Melalui aktif di CWC seorang mahasiswa juga telah melakukan rintisan masa depannya, hubungan baik dengan kawankawannya, dan hubungan fungsional dengan dunia luarnya. Semua dilakukan secara saling menguntungkan tanpa ada pihak yang dirugikan. Untuk selanjutnya, siap memasuki lapangan kerja nantinya.

Adapun bagi dosen, berarti ia mengarahkan aktivitasnya pada tugas utamanya sebagai dosen. Tugas utama sebagai dosen tentunya mengajar, mengabdi dan meneliti, serta menulis.

Sementara bagi lembaga, dengan semakin kreatif dan produktif menulis para civitasnya, maka dalam waktu yang tidak lama, bahkan dengan hitungan periode, dapat lahir sejumlah, puluhan bahkan mungkin ratusan karya tulis (artikel maupun buku), yang semakin hari semakin berkualitas. Itu artinya, lembaga akan semakin terangkat nama baiknya, sebagai lembaga yang produktif.

\section{Dugaan Hambatan}

Hambatan bagi CWC, meskipun tidak begitu berarti, bisa muncul dari aspek psikologis. Hambatan tersebut berupa kurangnya kesabaran dan ketekunan serta kerajinan berlatih dalam menulis. Tanpa menyadari kekurangannya dan tanpa ingin memperbaiki kekurangan itu, akan sulit bagi mereka untuk dapat sukses memasuki dunia tulis.

Akan tetapi, melalui sistem CWC yang solid, hal demikian akan dengan sendirinya tereliminasi, melalui suasana "persaingan yang positif" di antara anggota kelompok, saling nasehati, saling mengoreksi, saling bantu dan saling kerjasama dalam suasana sama-sama kerja. ${ }^{18}$ Dengan demikian, akan memungkinkan bagi para pemula untuk senantiasa bersabar dan senantiasa menjadi lebih baik dari hari ke hari. 


\section{Penutup}

Gagasan sederhana ini, merupakan gagasan terbuka untuk diaplikasikan oleh siapapun. Tidak terbatas pengaplikasiannya pada pelajar dan mahasiswa, tetapi juga oleh para dosen serta masyarakat umum. Penulis merasa bersyukur jika suatu saat dapat lahir semakin banyak kelompok-kelompok penulis dan bimbingan menulis, yang dari sana lahir mubaligh penulis yang handal dan produktif. Dengan begitu, tentu akan semakin baik bagi persaingan yang sehat, dan semakin memungkinkan lahirnya sejumlah tulisan-tulisan yang berkualitas. Begitu pula dambaan untuk tumbuh dan berkembangnya budaya tulis, dengan begitu dapat mendekati kenyataan. Semoga dalam sisa usia yang Allah amanahkan ini, kita dapat berbuat lebih baik dan lebih kreatif serta produktif, sehingga dapat "mewariskan" sejumlah karya bagi peradaban masa kini dan masa depan. Amin.

\section{DAFTAR PUSTAKA}

A. Hadi, Anda Ingin jadi Pengarang?, Surabaya: Usaha Nasional, 1981.

A. Siddiqi, Shamim, Metodologi of Dakwah, New York: The Forum for Islảmic Work, 1989.

AbuAl-Gifari, Kiat Menjadi Penulis Sukses, Bandung: Mujahid Press, 2002.

Armanda, Wina, Menggugat Kebebasan Pers, Jakarta: Pustaka Sinar Harapan, 1993.

Ash-Shiddiq, Alamat Surat Kabar dan Majalah Seluruh Indonesia, Bandung: Ash-Shidiq Press, 1998.

Bahar, Ahmad, Kiat Sukses Meraih Penghasilan dari Surat Kabar, Yogyakarta: Pena Cendikia, 1996. 
Cambell, David, Mengembangkan Kreativitas, Yogyakarta: Kanisius, Cet. III, 1990.

Cipta Loka Caraka, Teknik Mengarang, Yogyakarta: Kanisius, 1971.

Darmadi, Kaswan, Meningkatkan Kemampuan Menulis, Yogyakarta: Andi, 1996.

Daud Ibrahim, Marwah, Teknologi, Emansipasi dan Transendensia: Wacana Peradaban dengan Wacana Islami, Bandung: Mizan, 1994.

DP, Tampubolon, Kemampuan Membaca: Teknik Membaca Efektif dan Efisien, Bandung: Angkasa, 1990.

Gunther, Max, Writing The Modern magazine Article, Boston: The Writer, Inc. Publisher, 1982.

Hernowo (Ed.), Sebuah Buku Setetes Ilmu, Bandung: Mizan, 1991.

H. Assegaf, Dja'far, Jurnalistik Masa Kini, Jakarta: Ghalia Indonesia, 1992.

1. Rivers dkk, William,., Editorial, Bandung: Rosdakarya, 1989.

J. Bulatau S.J., Teknik Diskusi Berkelompok, Yogyakarta: Kanisius, Cet. 18, 2001.

J. Schwartz, David, Berpikir dan Berjiwa Besar, Jakarta: Binarupa Aksara, 1992.

J.B.A.F. Mayor Folak, Sosiologi Suatu Buku Pengantar Ringkas, Jakarta: Ichtiar Baru, 1976

Joyce Wycoff, Menjadi Super Kreatif Melalui Metode Pemetaan Pemikiran, Bandung: Kaifa, 2002.

Koentjaraningrat, Pengantar Ilmu Antropologi, Jakarta: Rineka Cipta, 1990

Koesworo,FX, Di Balik Tugas Kuli Tinta, Surakarta: Universitas Sebelas Maret, 1994.

Kusnawan, Aep, Berdakwah Lewat Tulisan, Bandung Mujahid Press,: 2004. 
- Teknik Debat Dalam Islam, Bandung: Pustaka Setia, 2003.

_- Ilmu Dakwah: Kajian Berbagai Aspek, Bandung: Pustaka Bani Quraisy, 2004.

- Komunikasi Penyiaran Islam, Bandung: Benang Merah Press, 2004.

Lindskoog, Katyn, Creative Writing for The People Who Can't Write, Michigan: Academie Books, Grand Rapids, 1989.

Magnis Suseno, Frans, Etika Dasar Yogyakarta: Kanisius, Cet. V,1993.

Moekijat, Latihan dan Pengembangan SDM, Bandung: Mandar Maju, 1991.

—, Dasar-dasar Motivasi, Bandung: Sumur Bandung, 1983.

Mohammad, Herry, Jurnalisme Islami: Tanggung Jawab Moral Wartawan Muslim, Jakarta: Pustaka Progresif, 1992.

Patmono SK, Teknik Jurnalistik, Jakarta: BPK Gunung Mulia, 1996.

Poerwadarminta, W.J.S, Bahasa Indonesia untuk Karang Mengarang, Yogyakarta: UP Indonesia, 1979.

Rogers, M. Eertt, Memasyarakatkan Ide-ide Baru, Surabaya: Usaha Nasional, 1987.

Samad, Daniel, Dasar-dasar Menresensi Buku, Jakarta: Grasindo, 1997.

Siregar (Peny.), Ashadi, Bagaimana Mempertimbangkan Artikel Opini Untuk Media Massa, Yogyakarta: Kanisius, 1995.

Soejito, Kalimat Efektif, Remaja Karya, Bandung: 1986.

Soeseno, Slamet, Teknik Penulisan Ilmiah Populer: Kiat Penulisan Fiksi untuk Majalah, Jakarta: Gramedia, 1995.

Syaikh Faisal Bin Aly Yahya Ahmad, Sistem Kaderisasi Rasulullah SAW, Solo: Pustaka Mantiq, 1994.

Syamsu dkk., Syahriman, Dinamika Kelompok dan Kepemimpinan, 
Yogyakarta: Universitas Atmajaya,1991.

Taufiq Hidayat, Rachmat, Tulisan Buku dan Peradaban, dalam Tim Penyusun, Buku untuk Pribadi Massa Depan, PP, Tasikmalaya: 1992.

Thalib Rahman, Abdul, Pedoman Penerapan Manajemen Berdasarkan Sasaran, Bandung: Renjana Swadwsi Utama, 1990.

Todd Siler, Berpikir Ala Enstein: Kiat Menjadikan Diri Anda Jenius, Bandung: Kaifa, 2001.

W. Amold, Thomas, The Preaching of Islam, Jakarta: Widjaya, 1981.

W. Arnold, Wilson, Nadeak, Bagaimana Menjadi Penulis yang Sukses, Bandung: Pustaka Wina, 1994.

__ Bagaimana Menjadi Penulis Artikel Kristiani yang Sukses, Bandung: Yayasan Kalam Hidup, 1989.

Wilson, Gerge E. \& Burks, Julia M., Lets Write English, New York: Lition Educational Publishing, 1980.

Youngberg, Norma, Creative Techniques, Pasific Press, Montain View, California: 1968. 